\title{
Modernismo de pés descalços Mário de Andrade e a cultura caipira
}

\author{
Ivan Marques ${ }^{1}$
}

\section{Resumo}

Depois das "palavras em liberdade" de Pauliceia desvairada, Mário de Andrade inaugurou, nos anos de 1920, uma nova fase de sua obra literária, que correspondia a uma reorientação do próprio Modernismo brasileiro: a busca da "contribuição milionária de todos os erros" (Oswald de Andrade, "Manifesto Pau Brasil"). Contra as regras da gramática e do discurso letrado, procurava-se imitar a "língua errada do povo". No caso de Mário de Andrade, o desejo de estilizar a fala popular resultou no projeto da Gramatiquinha da Língua Brasileira, que tinha no chamado dialeto caipira uma de suas inspirações. O diálogo com a cultura caipira ocorre em momentos centrais da sua produção literária: Macunaíma, Clã do jabuti, Os contos de Belazarte. Estudando a pintura de Tarsila do Amaral, Mário dirá que a sua brasilidade consiste no "caipirismo" das cores e das formas; algo que também se aplica, e mais radicalmente, à literatura cada vez mais enraizada de Mário de Andrade, na qual os "erros" de linguagem e a presença de personagens caipiras ou selvagens figuram o deslocamento do Brasil e o do próprio escritor em relação ao processo de modernização.

\section{Palavras-chave}

Modernismo, Mário de Andrade, língua brasileira, cultura caipira

Recebido em 1 de junho de 2012

Aprovado em 6 de julho de 2012

MARQUES, Ivan. Modernismo de pés descalços: Mário de Andrade e a cultura caipira. Revista IEB, São Paulo, n. 55, p. 27-42, 2012.

1 Professor doutor de Literatura Brasileira na Faculdade de Filosofia, Letras e Ciências Humanas da Universidade de São Paulo (USP, São Paulo, SP, Brasil). E-mail: ivmarques@uol.com.br 


\title{
Barefoot Modernism Mário de Andrade and the Rural Culture
}

\author{
Ivan Marques
}

\begin{abstract}
After exercising the boldness of "words in freedom" on his Pauliceia Desvairada futuristic verses, Mário de Andrade began a new phase in his literary work in the mid-1920's, which coincided with the reorganization of the Brazilian modernism itself, moved by the search for the "millionaire contribution of all mistakes" (an expression by Oswald de Andrade on Manifesto Pau-Brasil). Standing up against grammar rules and the literate discourse, modernists sought to emulate the "wrong language of the people", well aware that this would be the route to our "native originality". In the particular case of Mário de Andrade, the desire to define the popular speech resulted in a project called Gramatiquinha da Língua Brasileira (Brazilian Language Little Grammar), which had as one of its main inspirations the rural dialect. The dialogue with the Brazilian rural culture actually occurs in key moments of his writing in the 1920's: on the novel Macunaíma, on the Clã do Jabuti poems, and on the Os Contos de Belazarte suburban stories. By studying Tarsila do Amaral's paintings, Mário says its Brazilianness lies in the rural aspect of the colors and shapes - a principle that also applies, and even more radically, to his increasingly rooted writing, in which language "mistakes" and the presence of rural or wild characters represent the displacement of Brazil and the writer himself regarding the modernization process.
\end{abstract}

Keywords

Modernism, Mário de Andrade, Brazilian language, rural culture 


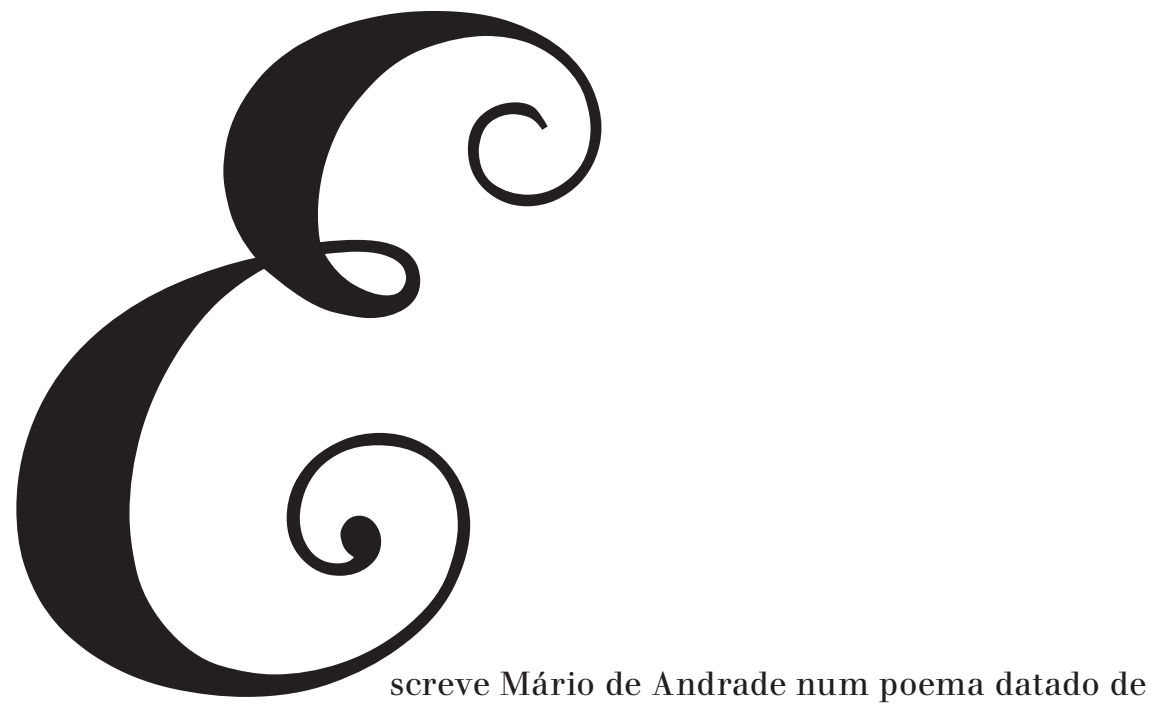
1924, publicado três anos depois na abertura da coletânea Clã do jabuti: "Estou com desejos de desastres". A composição tem ar de manifesto, mas está longe da pressa e da estridência que se observam, por exemplo, no "Prefácio interessantíssimo" de Pauliceia desvairada, escrito no começo da década. Por sua linguagem calma, rememorativa, esse poema estaria mais próximo do balanço, da lição ou do testamento, formas que não destoam, aliás, da intenção principal do livro, revelada já no título, isto é, a de enfeixar um repertório da diversidade cultural brasileira. Nosso primeiro modernismo, como mostrava agora o símbolo do jabuti, estava resolvido a procurar feição e ritmo próprios, depois de cultivar, na primeira fase em que o relógio nacional teve como referência a hora estrangeira, a miragem do futurismo e de outros "ismos".

Dedicado a Carlos Drummond de Andrade, "O poeta come amendoim" contém a apologia do que Mário chamou de "matavirgismo": a busca de um Brasil que o poeta sentia ser, conhecer de modo íntimo, e não simplesmente amar, recolher em seus aspectos exteriores, conforme a conhecida fórmula machadiana do ensaio "Instinto de nacionalidade", e que por sua particularidade comporia o acorde diferenciado, a contribuição singular do país ao concerto moderno das civilizações. Tal apologia, como se sabe, era na mesma época o tema central da correspondência - e da discordância - entre Mário e o "desenraizado" poeta mineiro.

De maneira pachorrenta, sentimental e sensual (quase voluptuosa), o poeta exibe o seu jeito não patriótico, mas interiorizado, de ligar-se ao país, que é devorado como se fosse amendoim. Depois de apresentar o Brasil como "sítio imenso", povoado de "cheiros e calores", e o brasileiro 
como homem marcado "de moreno" pelo sol, o poema vai enfileirando acontecimentos de diferentes períodos da história brasileira (relativos ao Primeiro Império, à Regência, à Abolição). É nesse momento que aparece o verso que transcrevemos no início - na esteira de outro "desastre" localizado no plano histórico:

$[\ldots]$

Porém o desastre verdadeiro foi embonecar esta república temporã.

A gente inda não sabia se governar...

Progredir, progredimos um tiquinho

Que o progresso também é uma fatalidade...

Será o que Nosso Senhor quiser!

Estou com desejos de desastres...

Com desejos do Amazonas e dos ventos muriçocas

Se encostando na cangerana dos batentes...

Tenho desejos de violas e solidões sem sentido

Tenho desejos de gemer e de morrer.

$[\ldots]^{2}$

É fácil notar a oscilação súbita, que ocorre com a distância de poucos versos, entre os dois significados. O substantivo "desastre" tem não apenas dupla ocorrência, mas dupla função no poema. No primeiro caso, como era de esperar, o termo diz respeito a um possível fracasso do Brasil, resultante de uma formação falha e incompleta, da maioridade precoce, do progresso não controlado ("uma fatalidade"), da república temporã e embonecada. Já no segundo caso, aparece positivamente associado a um elemento de outra natureza, o desejo, que é grafado no plural, pois se trata de algo insaciável, dirigido a múltiplos objetos.

"Estou com desejos de desastres" é o verso central, que divide o poema em duas partes. Após a digressão inicial de tema histórico, o que a segunda parte apresenta é a esperada declaração de amor incondicional pelo Brasil. A expressão “desejos de desastres” é seguida por reticências, mas seu sentido é explicitado na estrofe seguinte, que funciona como aposto. Nesse ousado segundo uso, a palavra "desastres" alude, portanto, a toda a gostosura das coisas brasileiras: ventos, Amazonas, violas, solidões, sem esquecer os cheiros e calores já mencionados. Retroativamente,

2 ANDRADE, Mário de. Poesias completas. São Paulo: Itatiaia, 2005, p. 161-162. 
a segunda ocorrência interfere na primeira, e do cruzamento das duas acepções distintas advém a conclusão: para o poeta otimista de Clã do jabuti - livro, segundo ele, "possivelmente Pau-Brasil" -, o descompasso político do Brasil, definido inicialmente como desastre, figuraria ao cabo a possibilidade de um rumo histórico alternativo, a um só tempo burguês e pré-burguês.

Esse desastre, do qual tantos se envergonhavam, não era produto de qualquer limitação ou incompetência, mas se devia unicamente à inadequação daquelas “ideias fora do lugar”. Algo que estávamos impondo a nós mesmos por nossa própria iniciativa, como diria Mário alguns anos mais tarde, voltando ao assunto em um artigo de jornal, no qual deplora outra vez o "erro principal do Brasil, e possivelmente inamovível”, qual seja, "estarmos querendo recriar em nossas grandezas e violências equatoriais, uma civilização europeia, prática, fria, dominada pela estupidez duma lógica grego-cristã, incapaz de reconhecer os direitos do corpo preguiçoso e os sombrais úmidos e misteriosos dum filosofismo místico-sensual. Se o Brasil adquirir uma civilização própria, esta há de se assemelhar muito mais às civilizações antigas do Egito, da Índia, da China, que às da Europa ou da América do Norte"

O Brasil tornou-se República sem que soubéssemos nos governar, diz o poema, acusando de "peculiar da vida brasileira" a ausência de organização. Nos termos de Sérgio Buarque de Holanda, que na década seguinte - e acompanhando de perto os passos de Mário de Andrade em Macunaíma - publicaria seu Raízes do Brasil, uma acentuação do afetivo e do irracional, paralelamente à estagnação ou atrofia das qualidades ordenadoras, disciplinadoras, racionalizadoras: "Quer dizer, exatamente o contrário do que parece convir a uma população em vias de organizar-se politicamente"4. Num poema tão representativo da nova fase que se abria no modernismo brasileiro, a acusação do despreparo político valia também como confissão de despaisamento e revisão daquele ímpeto de mimetização das vanguardas estrangeiras que caracterizara a "geração futurista" - época em que copiar o moderno parecia suficiente para sê-lo em suas próprias fronteiras, como se a civilização das máquinas e do progresso, num país "filho da cultura moderna", nos termos de Sílvio Romero, ou "moderno de nascença”, conforme uma definição bem mais recente, estivesse ao alcance dos dedos, fácil

3 ANDRADE, Mário de. "José Américo de Almeida", artigo de 16 nov. de 1930. In: LOPEZ, Telê Porto Ancona (org.). Táxi e crônicas no Diário Nacional. São Paulo: Duas cidades, 1976 , p. 276.

4 HOLANDA, Sérgio Buarque de. Raizes do Brasil. Rio de Janeiro: José Olympio, 1994, p. 31. 
de ser aclimatada e colhida. A partir de 1924, a volta à terra brasileira significou o reconhecimento do caminho difícil, pois os modernistas, agora enraizados, sabiam que teriam que lidar com impasses profundos. Nesse mesmo roteiro, porém, terminariam por afirmar, sempre de olho na Europa, aspectos da "diferença" nacional e a autenticidade maior do primitivismo por nós concebido, ao mesmo tempo que realizavam a superação de dualidades e inferioridades, o "desrecalque localista" (expressão de Antonio Candido) no qual se engastava, afinal, a possibilidade de um salto, outra vez mágico e imediato, em direção ao moderno.

Embora registrado negativamente no poema de Clã do jabuti, o primeiro desastre seria a confirmação de um idealizado desvio - o Brasil na contramão - que naquele momento atraiu o poeta, a exemplo do que ocorria com Oswald de Andrade. É exatamente como "desvio", embora sob os auspícios de um vanguardista estrangeiro, que se define a volta às origens primitivas no Manifesto Pau-Brasil, datado do mesmo ano de 1924: "Uma sugestão de Blaise Cendrars: - Tendes as locomotivas cheias, ides partir. Um negro gira a manivela do desvio rotativo em que estais. $\mathrm{O}$ menor descuido vos fará partir na direção oposta ao vosso destino"

A locomotiva posta nas mãos de um negro - o elemento bárbaro tão próximo de nós - é uma boa imagem da síntese, desejada pela poesia e pela pintura Pau-Brasil, entre o moderno e o primitivo. O negro girando a manivela também serve de imagem para a guinada do modernismo brasileiro em direção ao passado e à "originalidade nativa", com a consequente valorização de aspectos contrastantes da cultura nacional, isto é, de nossos desastres. Essa nova perspectiva, que se pretende não só irônica, mas também “ingênua” e "sentimental”, é reencenada num célebre poema oswaldiano de 1925:

Erro de Português

Quando o português chegou

Debaixo duma bruta chuva

Vestiu o índio

Que pena!

Fosse uma manhã de sol

O índio tinha despido

O português. ${ }^{6}$

5 ANDRADE, Oswald de. Poesias completas. Rio de Janeiro: Civilização Brasileira, 1972, p. 14-15.

6 Idem, p. 115 . 
O erro de que trata o título não é o gramatical, que será cultivado em larga escala pelos modernistas, mas o equívoco histórico e cultural que foi, segundo Oswald, a atitude de cobrir a nudez do índio (embonecá-lo, diria Mário) não só com roupas, mas com todo o peso da gramática, da moral, da metafísica, da religião. Descolonizar o Brasil - uma das metas da Antropofagia - significaria voltar atrás, refazer o encontro inaugural, despir o europeu, inverter o sentido da colonização, numa palavra, corrigir o "erro de português", ao qual o poeta atribui dimensões profundas, para além do que sugere a forma leve e ingênua do poema-piada. É para nos aproximar de nossas raízes primitivas, assim como fez o negro girando a manivela, que servirá a "contribuição milionária de todos os erros", apregoada no manifesto poucas linhas abaixo da referência a Blaise Cendrars e à guinada modernista. O que se buscará, com base nas realidades de "como somos" e "como falamos", é a língua "natural e neológica", a correção do "erro de português" pelos "erros de brasileiro", dos quais se enche a poesia de Pau-Brasil e a prosa de Miramar. O erro gramatical é uma tentativa de corrigir o desastre histórico, empreendida por Mário e Oswald com estratégias diferentes, mas a partir da mesma preocupação de reconhecer "os direitos do corpo preguiçoso".

"Desejos de desastres"... O desejo pelo qual suspirava não só o autor de Clã do jabuti, mas também os outros poetas inventores do modernismo de 1922, é o "desejo de nacionalidade" - fenômeno que para Mário de Andrade era generalizado e "inconsciente" no Brasil, manifestando-se como "premência, sofreguidão, precisão", conforme expressou na "Carta aberta a Alberto de Oliveira”, publicada em 1925 no terceiro número da revista Estética. Tal aspiração nacionalista resultou em dois esforços: libertar a língua das normas gramaticais portuguesas e descrever a cultura popular e as características psicológicas do brasileiro. A síntese de tudo isso, como se sabe, é a rapsódia publicada em 1928 - síntese e também implosão, questionamento, figuração de uma crise da qual Mário possuía plena consciência, embora tenha dito várias vezes que se surpreendeu com o desfecho de Macunaíma. A crise dizia respeito à descoberta da falta de "caráter" do homem brasileiro e à desconfiança no próprio futuro do país. Com sua mistura de entusiasmo e pessimismo, de galhofa e melancolia, esse livro agudamente crítico revela, entre tantas outras coisas, o desânimo sentido na ponta final do percurso, algo que poderia ser provocativamente chamado de desastre do desejo.

Antes disso, porém, havia a crença generalizada na contribuição milionária dos erros para a invenção de uma nacionalidade definida e original. À busca do desastre podem ser associadas todas as 
transformações importantes da poesia brasileira na década de 1920: não só o rebaixamento temático e a expressão coloquial (erigindo como modelo a "língua errada do povo" que "fala gostoso o português do Brasil", como diz Manuel Bandeira em "Evocação do Recife”), mas também os atributos comumente associados à guerrilha estética vanguardista, como liberdade das formas, mistura de estilos, humor, paródia e todas as armas usadas no combate às regras e convenções. Em outras palavras, no modernismo brasileiro o erro serviu tanto à primeira etapa de recusa da literatura "passadista", na qual se procurava "corrigir" o nosso atraso em relação à modernidade europeia, quanto à inflexão nacionalista da segunda fase, que implicou a busca da originalidade nacional ("ver com olhos livres", na conhecida fórmula oswaldiana), cujo reconhecimento nos deixaria, segundo o autor de Pau-Brasil, superiores às vanguardas estrangeiras ou, na perspectiva menos eufórica de Mário, portadores de um "acorde" próprio e de uma contribuição singular à harmonia universal.

No caso de Mário de Andrade, o desejo de "falar brasileiro" começou timidamente já no livro Pauliceia desvairada e assumiu expressão radical nos anos seguintes, quando o escritor, para chamar a atenção, resolveu forçar a nota do seu brasileirismo. Depois se convenceu de que não era preciso ir tão longe no processo de abrasileiramento da fala, bastando para isso "esquecer Portugal". A despeito dos exageros, que pareciam indicar uma prática selvagem e descompromissada, o projeto de "estilizar o brasileiro vulgar" se desdobrou em estudos linguísticos e reflexão teórica. A sistematização desse material deveria vir à luz na Gramatiquinha da língua brasileira, projeto do qual Mário acabou desistindo no final da década de 1920 (fracasso concomitante, pois, ao "desastre do desejo" exibido em Macunaíma) ${ }^{7}$.

Estilizar o que é vulgar, dar entidade ao incaracterístico, "gramaticalizar o erro"... As intenções são ousadas e, como se vê, também contraditórias: como seria possível submeter a regras o que se define justamente pela inconstância e falta de correção? Por outro lado, se falhou o projeto da Gramatiquinha, o mesmo não se pode dizer da estilização da fala brasileira que Mário levou a cabo de modo confessadamente pessoal e que muitos acusaram ainda de artificial, mas que se revelou, na verdade, eficaz e inspiradora - um modelo mesclado que certamente influiu na criação, ocorrida duas décadas depois, do estilo

7 Os originais do projeto foram reunidos por PINTO, Edith Pimentel. A gramatiquinha de Mário de Andrade: texto e contexto. São Paulo: Duas Cidades/Secretaria de Estado da Cultura, 1990. 
irrepreensível de Guimarães Rosa, ao mesmo tempo rústico e erudito. Nota-se facilmente o modo espontâneo como essa destacada figura do nosso modernismo soube introduzir no discurso vanguardista elementos da fala caipira. Nas cartas, sobretudo, o leitor de Mário de Andrade se compraz em observar o estilo desalinhado do escritor, que dizia escrever como se estivesse, como um bom matuto, metido em mangas de camisa: "Ninguém escreve como fala e eu sou como todos. Porém sucede que a maioria pra escrever veste fraque, alguns casacas e o resto o paletó de domingo, ao passo que eu me dispo até do paletó semanal"8. Mais uma vez, o despir(-se) surge como metáfora da liberdade e do desejo de errar, de realizar na contramão o caminho que levaria à identidade desnuda do escritor e do país.

A distância entre a língua escrita e a falada é ressaltada com ironia no nono capítulo de Macunaíma, a "Carta pras Icamiabas": "Ora sabereis que a sua riqueza de expressão individual é tão prodigiosa, que falam numa língua e escrevem noutra" ${ }^{\circ}$. Na construção do herói sem caráter, a inclinação para o erro se mistura à apologia do ócio, ao desejo de deitar na rede e adquirir novamente uma mentalidade primitiva. Mas o primitivismo não era um fim em si mesmo. Ou melhor, Mário intuía que o erro só poderia triunfar se os escritores se empenhassem na tarefa de “ajudar a formação literária, isto é, culta da língua brasileira”, conforme explicou em carta a Manuel Bandeira ${ }^{10}$.

Na correspondência com Drummond, o tema do "paletó" - isto é, do excessivo respeito à gramática - deu pano para mangas. Para atrair o poeta mineiro à causa modernista, Mário de Andrade procurava de todos os modos convencê-lo a ser menos culto e preconceituoso: "Carlos, devote-se ao Brasil, junto comigo. Apesar de todo o ceticismo, apesar de todo o pessimismo e apesar de todo o século 19, seja ingênuo, seja bobo,

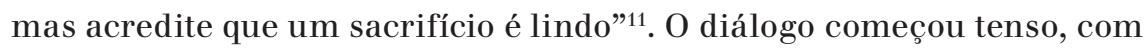
forte resistência de Drummond aos apelos reiterados do amigo, sempre timbrando na defesa da correção gramatical: "Ainda não posso compreender os seus curiosos excessos. Aceitar tudo o que nos vem do povo é

8 Idem, p. 327.

9 ANDRADE, Mário de. Macunaíma (edição crítica de Telê Porto Ancona Lopez). São Paulo/Rio de Janeiro: Secretaria da Cultura/Livros Técnicos e Científicos, 1978, p. 78 .

10 Carta de Mário a Bandeira, 25 jan. 1925. In: MORAES, Marcos Antonio de. (org.). Correspondência: Mário de Andrade e Manuel Bandeira. São Paulo: Edusp/IEB, 2001, p. 181.

11 Carta de Mário a Drummond,10 nov. 1924. In: FROTA, Lélia Coelho. Carlos e Mário: correspondência completa entre Carlos Drummond de Andrade e Mário de Andrade. Rio de Janeiro: Bem-Te-Vi, 2002, p. $5^{1}$. 
uma tolice que nos leva ao regionalismo [...]. Há erros lindos, eu sei. Mas que diabo, a cultura!... E poesia é também cultura"12. Erro e sacrifício, como se vê, são vistos como sinônimos, e não por acaso os dois missivistas lhes atribuem a qualificação de "lindos". O próprio Mário insistia na ideia de que sua obra - escrita em "língua imbecil" - estaria sendo intencionalmente atropelada: "Nós temos que dar uma alma ao Brasil e para isso todo sacrifício é grandioso, é sublime. [...] A minha vaidade hoje é de ser transitório. Estraçalho a minha obra. Escrevo língua imbecil, penso ingênuo, só pra chamar a atenção dos mais fortes do que eu pra este monstro mole e indeciso ainda que é o Brasil. [...] Que me importa que a minha obra não fique? [...] O importante não é ficar, é viver. Eu vivo" ${ }^{\text {13. }}$

Apesar de saber que a procura de uma língua brasileira, com seus inevitáveis excessos, poderia torná-lo um artista arruinado, Mário de Andrade se dizia disposto a "estraçalhar" sua obra, como se considerasse a inocência e a imbecilidade as únicas vias de acesso ao Brasil. Com efeito, o coloquialismo modernista não significou um mero combate ao refinamento da poesia parnasiana, mas sobretudo um esforço de aproximação e reconhecimento da realidade nacional. Por vezes Mário tomava ainda outra direção, tentando mostrar a Drummond que não estava "colecionando exemplos de estupidez" e que a fala dos brasileiros não seria assim tão incorreta: “O povo não é estúpido quando diz 'vou na escola', 'me deixe'..."14 Por sua vez, o poeta de Minas, embora defendesse inicialmente a linguagem culta e até mesmo clássica, rumaria com passos decididos, e lado a lado com Mário, Oswald e Bandeira, para a conquista de uma simplicidade que teve grande peso na vitória de nosso modernismo "heroico". Chegou inclusive a praticar alguns dos temidos exageros, como no escandaloso poema sobre a pedra, publicado em 1928 na Revista de Antropofagia, ou nos textos vanguardistas do periódico mineiro $A$ Revista, nos quais investiu pesado na experimentação ortográfica.

Livre e indisciplinada, a poesia dos anos posteriores à Semana de Arte Moderna já foi comparada a uma "criança em férias". Se a muitos pareceu ser uma moda descompromissada - um ataque às convenções, sem maiores consequências -, certamente não foi vista assim pelos artistas interessados naquele momento em "comer o amendoim", isto é, não só assumir as formas, mas expressar a "alma" do Brasil, seu dinamismo e seus desastres. Em cartas aos mais novos, Mário de Andrade

12 Carta de Drummond a Mário, zo dez. 1924. In: op. cit., p. 82.

13 Carta de Mário a Drummond, 10 nov. 1924. In: op. cit., p. 51.

14 Carta de Mário a Drummond, 18 fev. 1925. In: op. cit., p. 100. 
costumava dizer que o modernismo não era brincadeira infantil ou trabalho leviano, mas uma empreitada que exigia fôlego e aprofundamento. Para ser modernista, era necessário não só entusiasmo e aptidão para cambalhotas, mas principalmente muito estudo. No final da década de 1920 e sobretudo nos anos seguintes, o mesmo escritor que havia celebrado a inspiração, o desvairismo - e depois, visando ao Brasil, uma "arte ingênua, franca, boba, virgem" -, passaria a valorizar cada vez mais o artesanato e a disciplina, em termos parecidos com os que seriam utilizados mais tarde por João Cabral de Melo Neto, em sua defesa do "trabalho de arte". Leia-se, por exemplo, esta queixa registrada num artigo de 1939 sobre a poesia de Vinicius de Moraes: "Desapareceram os artistas do verso, e, o que é pior, poesia virou inspiração. [...] Ora, poesia é uma arte também, e isso de cantar como sabiá só fica bem para os sabiás do mato"15. Nessa época em que uma poesia de extração simbolista promovia uma reação às trivialidades e ao "anarquismo formal" dos poetas de 1922, o autor de Pauliceia desvairada, ao apregoar o estudo, para além da espontaneidade, não estava atribuindo razão aos adversários, mas, ao contrário, dando continuidade a uma consciência estética que existia desde a fase espaventosa dos erros - que não foram, portanto, desmedidos ou despropositados, e sim envolvidos em um projeto de sistematização.

"Não estou cultivando exotismos e curiosidades de linguajar caipira" - afirmava Mário em 1924 em carta a Drummond ${ }^{16}$. Visto como pitoresco e falso, o regionalismo foi repelido insistentemente pelo escritor cuja utopia, como se sabe, era abraçar, "organizar" e "estilizar" todo o Brasil. Mário queria "escrever brasileiro", e não simplesmente "escrever paulista" - daí a preocupação em podar os italianismos. No entanto, uma das bases da construção de sua fala desalinhada foi a cultura caipira, da qual se aproximou em inúmeras ocasiões, sobretudo no convívio com o mundo rural de Araraquara, onde veio a escrever as primeiras versões de Macunaíma. Nosso líder modernista atacava o regionalismo não porque seus objetivos fossem distintos, mas por buscar realizá-los de uma maneira não exótica. Seu desejo era fazer algo que o regionalismo, a seu ver, não soubera alcançar, isto é, a estilização sem preconceitos da fala rústica. Se pudesse àquela altura ter considerado as obras de João Simões Lopes Neto e Valdomiro Silveira - ou mesmo a do goiano Hugo de Carvalho Ramos, que ele viria a conhecer e admirar -, o escritor talvez

15 ANDRADE, Mário de. Belo, forte, jovem. In: . O empalhador de passarinho. Belo Horizonte: Itatiaia, 2002.

16 Carta de Mário a Drummond, 18 fev. 1925. In: op. cit., p. 100. 
não fosse tão crítico em relação à literatura regionalista, que no Brasil tem raízes profundas.

Publicado em 1920 por Amadeu Amaral, O dialeto caipira, estudo do linguajar utilizado pelos habitantes da área do vale do Paraíba, foi uma fonte valorizada de estudos para o projeto da Gramatiquinha da língua brasileira. Na criação de Macunaíma, foram igualmente importantes os conhecimentos relativos ao mundo rural paulista obtidos em conversas com os parentes de Araraquara, especialmente o fazendeiro Pio Lourenço Corrêa, com quem o autor se correspondeu ao longo de toda a vida. Mais que uma referência, a cultura caipira se tornou uma espécie de ideia fixa, sempre repontando nos escritos de Mário de Andrade a respeito da pesquisa de uma língua brasileira e de uma arte nacional. Em carta de 1923 a Tarsila do Amaral, que estava numa longa temporada com Oswald na França, o escritor afirma: "Considero vocês todos uns caipiras em Paris. [...] Tarsila, Tarsila, volta para dentro de ti mesma. [...] Abandona Paris! [...] Vem para a mata-virgem. [...] Criei o matavirgismo. Sou matavirgista. Disso é que o mundo, a arte, o Brasil e minha queridíssima Tarsila precisam. Se vocês tiverem coragem venham para cá, aceitem meu desafio"17. O cosmopolitismo, para Mário de Andrade, condenava o artista brasileiro à irrelevância - a mesma indefinição de Macunaíma, depois de perder a muiraquitã. Era de seu oposto que o mundo e o Brasil precisavam: assumir o caipirismo, recusando as imitações, era o caminho que conduziria o país à sua essência. No ano seguinte, ao resenhar o romance Memórias sentimentais de João Miramar para a Revista do Brasil, Mário encerra o texto com um comentário jocoso sobre o aparecimento da consciência nacional entre os modernistas de 1922:

Conhecem aquela história do caipira que ganhou umas botinas para votar no dr. Tal, deputado de profissão? Pois calçou-as e avançou na estrada. Os pés começaram a doer. O cabra não pôde mais. Tirou as botas e acariciou com olhos paternos os dedos que se mexiam livres, reconhecendo a terra amiga. "Tá contente, canaiada!" Esses modernistas brasileiros parece-me que descalçaram as botas. ${ }^{18}$

17 Carta de Mário a Tarsila, 15 nov. 1923. In: AMARAL, Aracy (org.). Correspondência: Mário de Andrade e Tarsila do Amaral. São Paulo: IEB/Edusp, 20o1, p. 78.

18 ANDRADE, Mário de. "Oswaldo de Andrade”, texto reproduzido como prefácio em Memórias sentimentais de João Miramar. São Paulo: Globo, 2004, p. 7-17. 
De pés descalços - ou em mangas de camisa, conforme a outra metáfora utilizada por Mário para definir sua linguagem desataviada -, o intelectual modernista gostava de se ver, assim, à semelhança do rústico e despachado homem caipira, cuja fala cheia de erros se procurou conhecer e estilizar. Essa guinada "provinciana”, que se ligava ao interesse renovado pela terra e pelo passado do país, parecia desviar o nosso modernismo do seu trilho vanguardista, com vistas para o futuro. Em 1914, Monteiro Lobato apelidou o nosso caboclo de Jeca Tatu e o pintou monstruosamente como feio, selvagem e preguiçoso - uma "velha praga", raça "a vegetar de cócoras, incapaz de evolução, impenetrável ao progresso"19. Apontado como estorvo no caminho da modernização, o caipira de modos grosseiros não deveria ter lugar na São Paulo moderna, rapidamente transformada em metrópole cosmopolita e industrial, "locomotiva" avessa às paisagens e figuras do passado. No entanto, na célebre conferência de 1942 denominada "O movimento modernista", Mário de Andrade faria questão de lembrar que São Paulo era habitada por caipiras, tendo sido palco do modernismo porque estava ao mesmo tempo "em contato mais espiritual e mais técnico com a atualidade do mundo" 20 . A cidade crescia, mas sua base era rural, caipira, e num momento em que muitos dela se envergonhavam, os modernistas resolveram reabilitá-la, girando a manivela do trem. De um lado, o progresso; do outro, o desvio ou desastre.

Num artigo publicado em 1927 no Diário Nacional, Mário afirma que a brasilidade de Tarsila do Amaral se devia não simplesmente à temática, mas ao desenvolvimento de uma forma caipira. Em sua opinião, dentro da história de nossa pintura, Tarsila foi a primeira que conseguiu realizar "uma obra de realidade nacional". O feito teria sido possível graças à operação que Antonio Candido chamou de "desrecalque", isto é, a partir do momento em que a artista deixara de se envergonhar de seu país:

Em Tarsila, como aliás em toda a pintura de verdade, o assunto é apenas mais uma circunstância de encantação; o que faz mesmo aquela brasileirice imanente dos quadros dela é a própria realidade plástica: um certo e muito bem aproveitado caipirismo de formas e de cor, uma sistematização inteligente do mau gosto que

19 LOBATO, Monteiro. Urupês. São Paulo: Globo, 2007, p. 169.

20 ANDRADE, Mário de. O movimento modernista. In: Aspectos da literatura brasileira. São Paulo: Martins, 1974, p. 236. 
é dum bom gosto excepcional, uma sentimentalidade intimista, meio pequena, cheia de moleza e de sabor forte. ${ }^{21}$

Na obra literária de Mário de Andrade, o caipirismo também desponta como tema e linguagem, e não só após a virada nacionalista de 1924. Essa presença é marcante desde os contos regionalistas escritos na década de 1910 e reunidos no volume Primeiro andar. O caipira reaparece depois em poemas e nas pungentes histórias do livro Os contos de Belazarte, escritas entre 1923 e 1926, enfocando tragédias vividas em espaços periféricos de São Paulo por personagens alheias ao processo de modernização. E o que dizer de Macunaíma, "imperador do mato virgem"? Ao herói esperto, mas sobretudo preguiçoso e abobalhado - compondo com seus irmãos um elenco de patetas que vivem desventuras na cidade grande -, colam-se à perfeição os atributos arrolados nas velhas tipologias do caráter nacional, exatamente os mesmos que eram deplorados na figura do pobre homem rural. No plano da linguagem, à sistematização do mau gosto que, segundo Mário, Tarsila realizava em sua pintura, corresponde à estilização do brasileiro vulgar que se vê na obra do escritor. Porém, enquanto Tarsila, “caipirinha vestida de Poiret”, seguia aplicando à nossa feiura o equilíbrio da arte cubista, comportando-se como inimiga dos excessos, Mário entregou-se ao aprendizado da deformação expressionista (mais adequada, segundo ele, à cultura informe do Brasil) e por esse motivo pôde realizar, mais radicalmente do que a estética ordenada de Pau-Brasil, uma obra de temas e feições caipiras.

Voltemos ao poema de abertura do livro Clã do jabuti. Os versos líricos e sensuais de "O poeta come amendoim" constituem um quadro típico que tem como ingredientes a "gostosura" da língua curumim, a "expressão muito engraçada", o "sentimento pachorrento" e o balanço das “cantigas amores e danças”, além dos já mencionados “desejos de violas e solidões sem sentido", tudo isso sendo mastigado e entronizado pelo autor. Tal composição não está distante de uma tela famosa de Almeida Júnior, Caipira picando fumo, datada de 1893. De acordo com Gilda de Mello e Souza, o pintor paulista representa um marco divisório na linha

21 ANDRADE, Mário de. Tarsila. In: Correspondência: AMARAL, Aracy (org.). Mário de Andrade e Tarsila do Amaral, op. cit., p. 13ı. Para Tarsila do Amaral, a estética Pau-Brasil significou um reencontro com sua infância no interior paulista. Num comentário sobre a viagem feita pelos modernistas, em 1924, às cidades históricas mineiras, a pintora conta que reencontrou ali as cores que admirava em criança: "Ensinaram-se depois que eram feias e caipiras. Segui o ramerrão do gosto apurado...”. Cf. AMARAL, Aracy. Tarsila: sua obra e seu tempo. São Paulo: Perspectiva/ Edusp, 1975, p. 121. 
evolutiva da arte nacional, pois "é com ele que ingressa pela primeira vez na pintura o homem brasileiro". Graças à análise do comportamento corporal do homem do campo, Almeida Júnior, segundo a ensaísta, teria podido "revitalizar a arte do Brasil" "22. É curioso observar como, embora suas escolhas tenham recaído em artistas diferentes, tanto Mário de Andrade quanto dona Gilda apontaram o "caipirismo" como elemento identificador da "cor local" e via de acesso à "realidade nacional".

No livro Alguma poesia, de 1930 - que Drummond dedicou a seu "amigo", retribuindo o gesto feito por Mário em "O poeta come amendoim" -, reencontramos não apenas o futurismo desconcertado da Pauliceia desvairada (ainda menos à vontade por conta do ambiente acanhado de Minas Gerais), mas também as imagens de uma "vida besta" e de um país estrambótico, as quais serviam como antídoto à marcha do progresso e como guia do poeta perdido na grande cidade. Drummond reutiliza, com tratamentos novos e menos pitorescos, motivos do nacionalismo literário como as violas, o luar, a tristeza e a cachaça, todos incluídos por Paulo Prado em seu ensaio de 1928 sobre a alma romântica dos brasileiros. Ainda que realize uma forte autocrítica, fazendo com que o lirismo seja constantemente sabotado pela inteligência, o poeta atribui a si mesmo muitas dessas imagens e traços da nacionalidade. $\mathrm{O}$ espírito romântico, por exemplo, é assumido em composições famosas como o "Poema de sete faces", em que o eu lírico afirma, selando seu individualismo, que seu coração é mais vasto que o mundo, e o poema “Explicação”, escrito em 1926 e considerado por Mário de Andrade um "peso-pesado", a composição que deveria abrir o livro. Os versos de “Explicação" são, ao mesmo tempo, manifesto poético, confissão lírica e reflexão sociológica. Para se "explicar", o poeta de um modo enviesado dá voz ao "mulato inzoneiro", produto da mestiçagem, sonso e cheio de manhas - que é o mesmo brasileiro de "O poeta come amendoim", também aqui mastigado e incorporado, mas sem que o espírito conciliador impeça o aparecimento, aqui e ali, de notas irônicas: "Não sou alegre. Sou até muito triste./ A culpa é das bananeiras de meu país, esta sombra mole, preguiçosa"; "E a gente viajando na pátria sente saudades da pátria"; "No elevador penso na roça,/ na roça penso no elevador". O verso torto do poeta é associado ao deslocamento histórico brasileiro, do qual o maior representante seria o tipo de origens rurais, posto entre o peso do passado e os anseios de modernização. Logo se compreende porque a poesia de Drummond, atando dessa maneira o sujeito poético e

22 Cf. MELLO E SOUZA, Gilda de. "Pintura brasileira contemporânea: os precursores". In: . Exercícios de leitura. São Paulo: Duas Cidades, 1980, p. 223-228. 
os (des)caminhos do Brasil, já foi definida com a expressão paradoxal de "lirismo sociológico".

Anterior à primeira redação de Macunaíma, que se daria poucos meses depois, naquele mesmo ano de 1926, "Explicação" parece exibir em primeira mão o anúncio de um novo desvio da rota - a introdução do nacionalismo crítico e do realismo problemático, para além da retórica conciliadora do sentimento nacional, que, por sua vez, tinha pretendido substituir o velho brasileirismo exterior e pitoresco. Aparecendo tardiamente, já na virada da década, Alguma poesia foi o último livro do nosso modernismo heroico a ser publicado e representou uma síntese das várias tendências daquele período. No poema "Explicação" e em outros, como "Fuga", "Também já fui brasileiro" e "Europa, França e Bahia", peças assumidamente críticas da literatura de 1922, o autor reconsidera não só os desejos, mas também os desastres do nosso modernismo - não só a busca da identidade nacional, com vistas à construção do futuro, mas a implosão dessa pesquisa, de que o herói Macunaíma, reduzido a estilhaços no final da narrativa, ficou sendo a principal representação.

Ao descalçar as botas, falando com gostosura a língua brasileira, os modernistas não só reconheceram, aliviados, a "terra amiga", como também foram obrigados a revolver esse território de contradições e irresoluções, as quais foram aos poucos aprendendo a pensar. Mas o processo todo - que, aliás, ainda está em curso - é bastante revelador. Antes cheia de complexos, a nossa elite se deu conta naquele momento de que o caipira deslocado em face do mundo moderno era uma das expressões profundas de nossa "alma nacional". O que se aprendeu não foi pouco: como disseram Otília Arantes e Paulo Eduardo Arantes, finalmente se teve consciência de que "é preciso ser 'moderno' o suficiente para não se acanhar mais de ser também “caipira"” ${ }^{23}$. Fora daí não seria possível, no Brasil, a construção de qualquer modernismo.

23 Cf. ARANTES, Otília e EDUARDO ARANTES, Paulo. Moda caipira. In: Sentido da formação: três estudos sobre Antonio Candido, Gilda de Mello e Souza e Lúcio Costa. São Paulo: Paz e Terra, 1997, p. 83. 